\title{
45. CRETACEOUS SAPROPELIC DEPOSITS OF DEEP SEA DRILLING PROJECT SITES 463, 465, AND 466 ${ }^{1}$
}

\author{
P. P. Timofeev and L. I. Bogolyubova, Geological Institute of the U.S.S.R. Academy of Sciences, Moscow, U.S.S.R.
}

\section{INTRODUCTION}

The wide distribution of sapropelic deposits in the sedimentary cover of the oceans, their Cretaceous age, and their possible oil- and gas-generating characteristics allow us to regard these deposits as a regular global stage in the history of oceanic sedimentation. So, Cretaceous sapropelic deposits are a unique object for study.

Cretaceous sapropelic deposits of DSDP Sites 463, 465 , and 466 (Fig. 1), as well as similar sediments of the Atlantic and Indian Oceans, are characterized by enrichment in organic matter, which sometimes reaches 33\% (Cape Verde Basin, DSDP Sites 367 and 368). Characteristics of these sediments are summarized in Table 1, and in Figure 2.

The objective of this study is the elucidation of genesis, paleogeographic environment of sedimentation, and oil-generating potential of Cretaceous sapropelic deposits at these sites. Attention is given to petrographic composition and distribution of the organic matter.

\section{PETROGRAPHIC COMPOSITION AND CATAGENETIC STAGE OF ORGANIC MATTER IN CRETACEOUS SAPROPELIC DEPOSITS}

Organic matter of these deposits is finely dispersed. Its petrographic composition was studied with a polarizing microscope, using bilaterally polished thin sections; products of maceration were used for this purpose. A more detailed identification of microcomponents of the organic matter was also accomplished. The general study of the organic-matter composition and its structure and distribution in the sediment was carried out at magnifications of 150 to 200 times; more-detailed characteristics of the inner structure of some fragments - their shape and size-were studied at 400 to 1000 times magnification, with a dry objective, in oil immersion, crossed nicols, and without an analyzer.

The terminology and description of petrographic microcomponents of organic matter are given in accordance with the classification of organic matter of sediments penetrated by deep-sea drilling in the eastern and northern Atlantic suggested by Bogolyubova and Timofeev (1978) and Timofeev and Bogolyubova (1979).

The organic matter of Cretaceous deposits from Sites 463,465 , and 466 abounds in sapropelic microcompo-

\footnotetext{
${ }^{1}$ Initial Reports of the Deep Sea Drilling Project, Volume 62.
}

nents represented by alginite-thallomite and saprocollinite. Humic microcomponents are, as a rule, in subordinate amounts. This is mainly an allochthonous gelinite-telinite " $A$ " (vitrinite), the genesis and rank of which are related to the source of supply of terrigenous material. Gelinite-telinite "A" has the shape of fragments with distinct contours, frequently with partings, and is characterized by red-brown color and absence of luminescence. It does not show any remains of cellular structure of plant tissues and is, therefore, completely homogeneous. The allochthonous humic material is sometimes represented by fragments of fusinite (xylovitrain-fusain) of black color and with hardly noticeable remains of cellular structure of plant tissues. Autochthonous humic microcomponents observed as formal elements (gelinite-telinite " $C$ ", in particular), the genesis and rank of which are associated with processes of accumulation and diagenesis of sediments of the basin, are rare within the organic matter of the studied Cretaceous deposits. Humic autochthonous microcomponents in the form of gelinite-collinite (lumpy granular flocculent "groundmass") are not visible under a microscope, although they may be present in the organic matter of the deposits under study.

No liptinitic microcomponents were recognized in thin sections; in products of maceration these are represented by a small amount of pollen grains. So, their role in determination of the type of organic matter is not significant.

Sapropelic matter is a typical autochthonous constituent of organic matter. It includes microcomponents of two types: alginite-thallomite and sapro-collinite. The alginite-thallomite type consists of microscopic plant organisms that under considerable magnification are of a round or oval shape and body size from 4 to $20 \mu \mathrm{m}$ and over. (Colonial algae, the body of which is named "thallome," have been attributed by us to alginitethallomite. Therefore, the described monocellular plant organisms can be conventionally assigned to alginitethallomite.) Their color in transmitted light is more or less dark brown, seldom yellow with an orange or olive tint. Most of them are characterized by granular structure in transmitted and reflected light, and they have distinct outlines. The brown bodies show very weak luminescence of brownish-red tints. Yellow-orange or olive bodies give bright orange luminiscence. These microorganisms likely belong to cysts of microscopic dinoflagellate algae.

Sapro-collinite in transmitted light is represented by a structureless flocculent or lumpy groundmass of beige- 


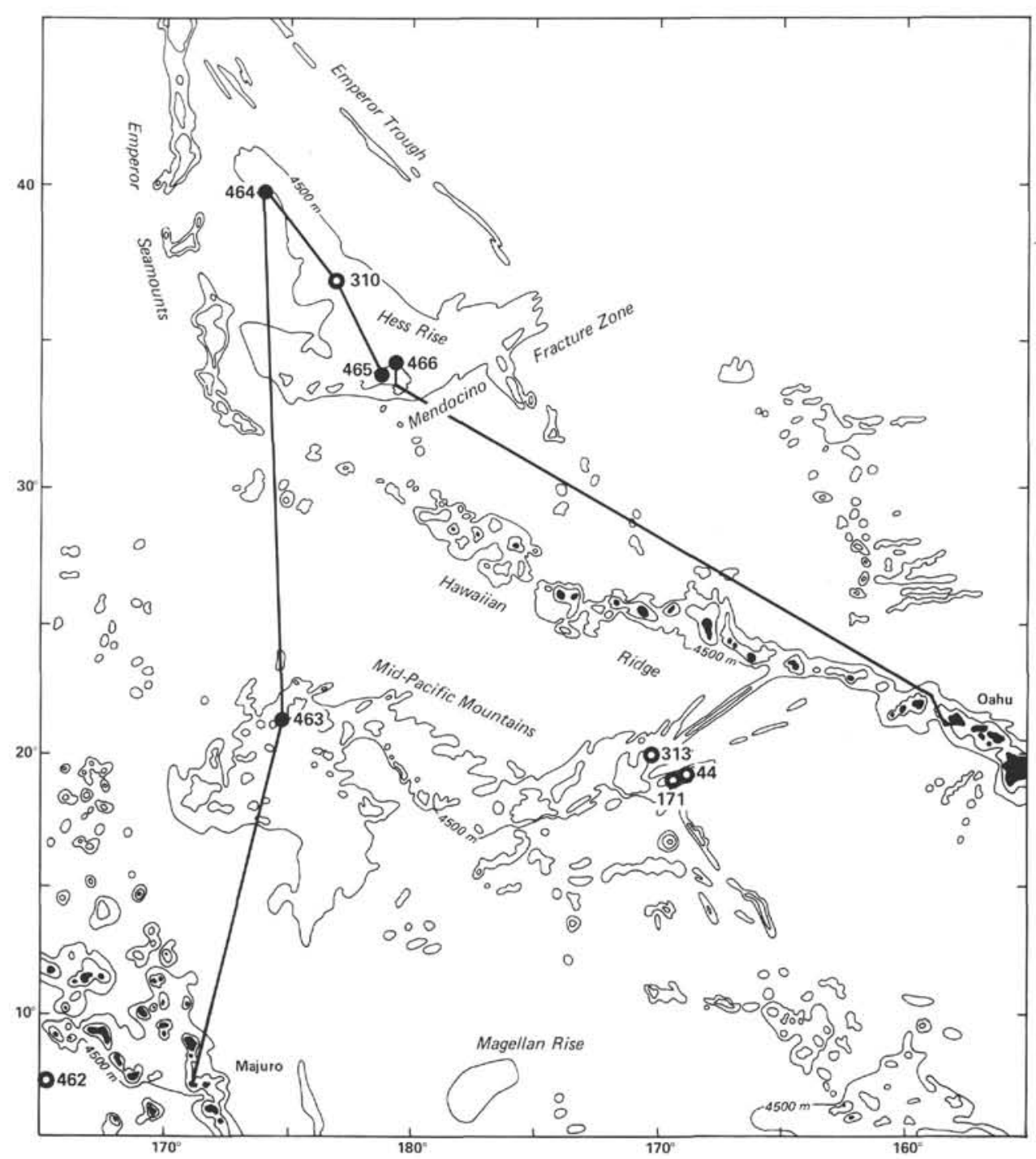

Figure 1. Deep Sea Drilling Project sites in the north-central Pacific. Black circles: sites containing Cretaceous sapropelic deposits; white circles: sites not studied.

olive or brownish color. It shows unusual brown-red luminescence with an orange tint. The original material of sapro-collinite is composed not only of products of decomposition of planktonic algae with plant and mineral shells, but also animal organisms. These are foraminifers, radiolarians, various mollusks, fish, etc. Sapro-collinite may also contain a certain admixture of colloidal humic material. Sapro-collinite is sorbed by the mineral matter of a sediment, forming an organicmineral mixture.

The total amount of organic matter in various beds of the Cretaceous deposits varies within wide limits. In sediments of Site 463 , organic carbon varies from 1.0 to $5.5 \%$; in those of Site $465 \mathrm{~A}$, from 0.1 to $8.6 \%$; at Site 466 from 0.7 to $7.5 \%$. The organic-matter content is responsible for the color of the sediment, which under the microscope varies from beige-olive to brownish. Alternation of layers with higher and lower contents of organic matter causes the lamination of the sapropelic deposits (horizontal; horizontally wave-like; crosslaminated; small gentle oblique).
The organic matter of Cretaceous sapropelic deposits of these sites (microcomponent composition being similar, on the whole) differs somewhat in the ratio of sapro-collinite and alginite-thallomite, in peculiarities of their distribution in sediments and an admixture of humic material.

The organic matter of lower Aptian sapropelic deposits from Site 463 (Core 70 ) is characterized by an almost complete absence of microscopically visible autochthonous and allochthonous humic material, as well as by finely lenticular, veined, or patchy distribution of sapropelic material in sediments containing greater or lesser amounts of well-preserved alginite-thallomite. Owing to this distribution of organic matter, the sediment acquires horizontal bedding (Plate 1, Fig. 1), or, in places, chaotic bedding (Plate 1, Fig. 2).

The organic matter of the lower part of the series of sapropelic deposits at Site 465 (Cores 37-40) contains appreciable amounts of humic material, represented by allochthonous microcomponents (gelinite-telinite "A"vitrinite). The sapropelic material abounds in sapro- 
Table 1. Genetic types, facies, and macrofacies of Cretaceous sapropelic deposits of Sites 463,465 , and 466.

\begin{tabular}{|c|c|c|c|c|c|}
\hline Site & Genetic types of sediments & $\begin{array}{c}\text { Symbol in } \\
\text { Figure } 2\end{array}$ & Facies & $\begin{array}{l}\text { Symbol in } \\
\text { Figure } 2\end{array}$ & Macrofacies \\
\hline 463 & $\begin{array}{l}\text { Carbonaceous, ashy, and silicified lime- } \\
\text { stone, gray to dark-gray, sometimes black } \\
\text { with an olive tint, with more-or-less } \\
\text { distinct horizontal, partly chaotic bedding, } \\
\text { large amounts of radiolarians, ash, } \\
\text { organic matter }(0.1-5.5 \%) \text { of sapro- } \\
\text { collinite and alginite-thallomite } \\
\text { composition }\end{array}$ & 1 & $\begin{array}{l}\text { Biogenic calcareous-siliceous } \\
\text { sediments with auto- } \\
\text { chthonous sapropelic micro- } \\
\text { components of a relatively } \\
\text { deep-water zone of marine } \\
\text { sedimentation }\end{array}$ & a & $\begin{array}{l}\text { Sapropelic-calcareous-siliceous } \\
\text { deposits of relatively deep } \\
\text { water, with active ash fall }\end{array}$ \\
\hline \multirow[t]{5}{*}{465} & $\begin{array}{l}\text { Foraminifer-nannofossil limestone, gray to } \\
\text { dark-gray with an olive tint, homo- } \\
\text { geneous, partly horizontally laminated } \\
\text { with organic matter }(0.1-2.5 \%) \text { of sapro- } \\
\text { collinite and alginite-thallomite } \\
\text { composition }\end{array}$ & 6 & $\begin{array}{l}\text { Carbonate sediments with } \\
\text { autochthonous sapropelic } \\
\text { microcomponents of organic } \\
\text { matter of relatively deep- } \\
\text { water, remote from the } \\
\text { shore }\end{array}$ & c & $\begin{array}{l}\text { Sapropelic and humic- } \\
\text { sapropelic carbonate deposits } \\
\text { of a near-shore sedimentation } \\
\text { zone }\end{array}$ \\
\hline & $\begin{array}{l}\text { Foraminifer-nannofossil limestone, gray, } \\
\text { sometimes dark-gray and black with an } \\
\text { olive tint, with more-or-less horizontal } \\
\text { lamination, organic matter }(0.1-1.9 \% \text {, } \\
\text { sometimes } 6.1 \%) \text { of sapro-collinite and } \\
\text { alginite-thallomite composition }\end{array}$ & 5 & & & \\
\hline & $\begin{array}{l}\text { Foraminifer-nannofossil limestone, gray to } \\
\text { dark-gray with an olive tint, with horizon- } \\
\text { tal lamination, partly small, gentle cross- } \\
\text { laminations, organic matter }(0.1-8.6 \%) \text { of } \\
\text { sapro-collinite and alginite-thallomite } \\
\text { composition }\end{array}$ & 4 & & & \\
\hline & $\begin{array}{l}\text { Foraminifer-nannofossil limestone, gray to } \\
\text { dark-gray and black with an olive tint, } \\
\text { with horizontal lamination, partly small, } \\
\text { gentle cross-laminations, organic matter } \\
(0.1-7.5 \%) \text { of sapro-collinite and alginite- } \\
\text { thallomite composition, with vitrinite }\end{array}$ & 3 & $\begin{array}{l}\text { Carbonate sediments with } \\
\text { autochthonous sapropelic } \\
\text { and allochthonous humic } \\
\text { microcomponents of organic } \\
\text { matter of a shallow-water } \\
\text { near-shore sedimentation } \\
\text { zone }\end{array}$ & & \\
\hline & $\begin{array}{l}\text { Foraminifer-nannofossil limestone, gray to } \\
\text { dark-gray with an olive tint, horizontally } \\
\text { wave-like, unidirectional, flattened cross- } \\
\text { lamination, a higher content of ter- } \\
\text { rigenous material, crystals and interbeds } \\
\text { of dolomite, organic matter }(0.2-3.5 \%) \text { of } \\
\text { sapro-collinite and alginite-thallomite } \\
\text { composition, abundance of vitrinite }\end{array}$ & 2 & $\begin{array}{l}\text { Carbonate sediments with } \\
\text { autochthonous sapropelic } \\
\text { microcomponents of } \\
\text { organic matter of relatively } \\
\text { deep-water, remote from } \\
\text { shore }\end{array}$ & & \\
\hline 466 & $\begin{array}{l}\text { Foraminifer-nannofossil ooze (chalk), gray } \\
\text { to dark-gray and black with an olive tint, } \\
\text { homogeneous or slightly horizontally } \\
\text { laminated with roiling structures, organic } \\
\text { matter }(0.1-7.5 \%) \text { of sapro-collinite and } \\
\text { alginite-thallomite composition }\end{array}$ & 4 & $\begin{array}{l}\text { Carbonate sediments with } \\
\text { autochthonous sapropelic } \\
\text { microcomponents of organic } \\
\text { matter of relatively deep- } \\
\text { water, remote from shore }\end{array}$ & c & \\
\hline
\end{tabular}

collonite containing small amounts of alginite-thallomite. Distinct localization of sapropelic material in sediments is peculiar. This material forms strands, veins, and lenticular band-like areas, stretching along the strike, frequently framing foraminifers, fragments of mollusk shells, fish bones, and other components of the sediment. Such distribution imparts a distinct, thin, horizontal, horizontally wave-like (Plate 1, Fig. 3), and fine cross lamination (Plate 2, Fig. 2) to the sediment in almost all cases.

The middle part of the strata of sapropelic deposits (Cores 28-36) is characterized by an almost complete absence of microscopically visible humic material, which is represented by fragments of gelinite-collinite "A." The sapropelic material here, as well as in the underlying strata, is composed predominantly of saprocollinite with alginite-thallomite within it; particles are much smaller than those observed in the lower strata, and they are frequently found in small accumulations. The sapropelic matter unevenly saturates a sediment, forming lenticular lenses; thin, band-like inclusions; and sometimes mottles and veins. This distribution of organic matter is responsible for the horizontal and small, flattened cross-lamination of sediments (Plate 2, Figs. 1-3).

The organic matter of the upper part of the sapropelic deposits (Cores 26 and 27) is similar in composition to that in the middle strata, but the inclusions here are larger. More or less even distribution of organic matter in a sediment is characteristic, without distinct localization; however, some mottles with greater or lesser content are observed as well. Such distribution of organic matter produces uniform texture in the sediment; thin, horizontal lamination is only sometimes observed (Plate 3, Fig. 3).

Sapro-collinite predominates in the organic matter of sapropelic deposits of Site 466. Alginite-thallomite inclusions, evenly distributed in sapro-collinite, are of larger size than those recognized in sediments of the aforementioned sites. Humic material is sporadic and 
HOLE 465A

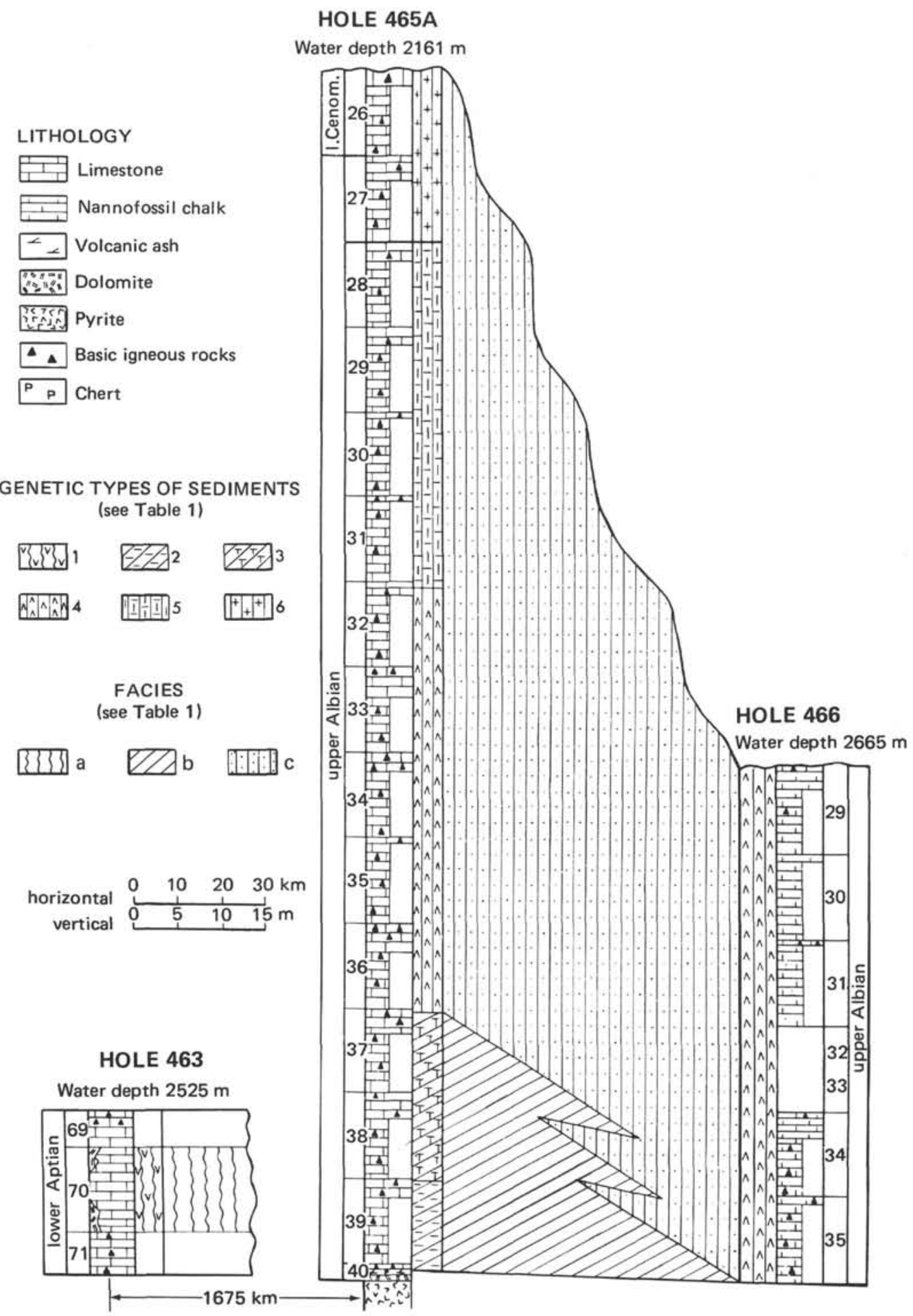

Figure 2. Schematic profile of Cretaceous deposits through Holes 465A and 466, and lithologic section at Site 463. Genetic types of sediments and facies explained in Table 1.

represented by gelinite-tellinite "A," sometimes gelinite-tellinite " $\mathrm{C}$ " and fusinite. The organic matter is not localized in a sediment and is distributed more or less evenly. As a result, the sediments become homogeneous or slightly horizontally laminated (Plate 3, Fig. 5).
Thus, analysis of petrographic composition of organic matter of Cretaceous deposits from Sites 463, 465 , and 466 shows that it belongs essentially to the sapropelic type, and only the organic matter of the lower part of the Cretaceous beds from Site 465 is mixed (humic-sapropelic). According to the chemical analysis 
summarized in Table 2 and in the diagram of Van Krevelen (1951/1952) (Fig. 3), kerogen, i.e., insoluble residual organic matter, gravitates towards the mixed humic-sapropelic type. Proceeding from the data of petrographic and chemical study, disagreement in determination of the type of organic matter can be explained as follows: all elements of the organic matter, as well as its colloidal constitutents, i.e., gelinite-collinite, etc., are identified by microscopic petrographic study. The humoid structures peculiar to sapropelic material being products of polymerization of fatty materials, are not recognizable by means of petrographic studies, and their existence was revealed through their chemical characteristics (elemental composition). Identified with the help of Van Krevelen's diagram, the sapropelic substance owes its seemingly sapropelic-humic and humic-sapropelic composition to humoid structures. So it proves to belong to Group II or Group II-III types (Fig. 3). Consequently, the diagram compiled by Van Krevelen fails to define the nature and genesis of the organic matter. It only represents its chemical characteristics.

Investigations of postsedimentary evolution of the organic matter of Cretaceous sapropelic deposits from these sites showed that the matter is at the stage of diagenesis or initial protokatagenesis in the general scheme of lithogenesis of sedimentary rocks (Vassoevich, 1975). This is evidenced by low reflectance values of alginite-thallomite $\left(R_{\max }^{\circ}=0.24-0.26 \%\right)$ and autochthonous vitrinite $\left(R_{\max }^{\circ}=0.37-0.42 \%\right)$, as well as by cristobalite in the mineral matter of the sediments. The combination of sapropelic and humic-sapropelic types of organic matter with the low stage of katagenesis allows attribution of the Cretaceous deposits of Sites 463,465 , and 466 to the category of potentially oilgenerating beds.

\section{GENETIC TYPES, FACIES, AND STRUCTURES OF CRETACEOUS SAPROPELIC DEPOSITS FROM SITES 463, 465, AND 466}

Cretaceous sapropelic deposits of these sites are of various ages (Fig. 2). At Site 463, in the western MidPacific Mountains, lower Aptian sapropelic deposits were drilled ( $9.5 \mathrm{~m}$ only; Core 70 ).

Hole $465 \mathrm{~A}$, on the southern slope of Hess Rise, penetrated upper Albian and lower Cenomanian sapropelic deposits (134.5 m; Cores 26-40). At Site 466, in the same region as Site 465 , the sapropelic deposits $(57 \mathrm{~m}$; Cores 29-35), belong to the upper Albian; higher in the section, Cenomanian sediments are missing.
Considering the differences in the material composition of sapropelic deposits, genetic types of sediments and their facies and macrofacies were distinguished. They reflect specific features of Cretaceous sedimentation in the regions of the Pacific Ocean sites under study.

Distinction of genetic types of sapropelic deposits was based on the following features: (1) material composition and color; (2) structure and texture of sediments; (3) the organic-hydrogen content and microcomponent composition of the organic matter; (4) amount, composition, and size of faunal remains; (5) composition of authigenic minerals; (6) position of genetic types of sediments in a section and area and their relationships between each other. The genetic types of the same material composition are united into certain facies; some of the latter with similar conditions of formation compose macrofacies. The list of the established genetic types of sapropelic deposits at Site 463,465 , and 466 , and their brief characteristics and corresponding facies and macrofacies are given in Table 1.

Below is a brief description of Cretaceous sapropelic deposits both stratigraphic and geographic, in the region of the Pacific Ocean under study:

A series of lower Aptian sapropelic deposits at Site 463 in the Mid-Pacific Mountains region overlies a carbonate-siliceous tuffaceous series (Timofeev and Rengarten, this volume). It belongs to the macrofacies of sapropelic-calcareous-siliceous deposits of relatively deep-sea sedimentation (Table 2; Fig. 2). The section (Core 70) is composed of one genetic type of sediment (Table 1), represented by carbonaceous, ashy, and silicified limestone, of gray, dark-gray, and sometimes olive-black color. The intensity of color varies, depending on the content of sapropelic organic matter, which in the lightest layers is from 0.1 to $0.55 \%$, and in dark and olive-black layers reaches 3.0 to $5.5 \%$. Some darker layers are enriched in ash, not organic carbon. The layers differing in colors alternate in the section, imparting indistinct to pronounced horizontal laminations (Plate 1, Fig. 1). The thickness of laminae varies from a few centimeters to several millimeters. The boundaries between them are more or less distinct, with traces of burrows, scour, and redeposition in places. Sometimes the dark-colored parts look like impregnations of small lenses, or inclusions of an indefinite shape within the gray matter of a sediment, this being responsible for chaotic bedding (Plate 1, Fig. 2).

While analyzing the material composition of this genetic type of sediment, we observed as a rule abun-

Table 2. Chemistry of the organic matter.

\begin{tabular}{|c|c|c|c|c|c|c|c|c|c|}
\hline \multirow[b]{2}{*}{ Hole } & \multirow{2}{*}{$\begin{array}{c}\text { Sample } \\
\text { No. }\end{array}$} & \multirow[b]{2}{*}{ Sampled Interval } & \multirow{2}{*}{$\begin{array}{c}\mathrm{C}_{\text {org }} \\
\text { in Rock }\end{array}$} & \multirow{2}{*}{$\begin{array}{c}\text { Kerogen } \\
\text { Ash } \\
\text { Content }\end{array}$} & \multicolumn{3}{|c|}{$\begin{array}{l}\text { Elemental Composition } \\
(\%)\end{array}$} & \multirow{2}{*}{$\begin{array}{c}\mathrm{H} / \mathrm{C} \\
\text { (atomic) }\end{array}$} & \multirow{2}{*}{$\begin{array}{c}\mathrm{O} / \mathrm{C} \\
\text { (atomic) }\end{array}$} \\
\hline & & & & & $\mathrm{C}$ & $\mathrm{H}$ & $\mathrm{O}+\mathrm{S}+\mathrm{N}$ & & \\
\hline 463 & 1 & $70-5,112-116 \mathrm{~cm}+70-5,7-13 \mathrm{~cm}$ & 2.32 & 30.14 & 70.68 & 5.44 & 23.88 & 0.92 & 0.25 \\
\hline $465 \mathrm{~A}$ & 2 & $39-1,121-122 \mathrm{~cm}+38-1,46 \mathrm{~cm}$ & 0.64 & 3.41 & 68.33 & 7.07 & 24.60 & 1.24 & 0.28 \\
\hline 465 & 3 & $38-1,73 \mathrm{~cm}+37-2,76 \mathrm{~cm}+38-1,75 \mathrm{~cm}$ & 2.32 & 2.59 & 69.05 & 7.44 & 23.51 & 1.29 & 0.26 \\
\hline $465 \mathrm{~A}$ & 4 & $37-2,23 \mathrm{~cm}+37-1,103 \mathrm{~cm}$ & 3.50 & 4.70 & 72.06 & 7.56 & 20.38 & 1.26 & 0.21 \\
\hline $465 \mathrm{~A}$ & 5 & $32-1,96 \mathrm{~cm}+32-1,84 \mathrm{~cm}+32-1,38 \mathrm{~cm}$ & 1.09 & 20.44 & 71.89 & 6.13 & 21.98 & 1.02 & 0.23 \\
\hline $465 \mathrm{~A}$ & 6 & $30-1,23 \mathrm{~cm}+33-2,20 \mathrm{~cm}$ & 1.76 & 5.14 & 68.86 & 6.71 & 24.43 & 1.17 & 0.27 \\
\hline $465 \mathrm{~A}$ & 7 & $27, \mathrm{CC}, 16 \mathrm{~cm}+27-2,47 \mathrm{~cm}$ & 2.18 & 4.38 & 69.59 & 6.82 & 23.59 & 1.18 & 0.25 \\
\hline 466 & 8 & $34-1,108 \mathrm{~cm}+35-1,61 \mathrm{~cm}$ & 2.91 & 2.45 & 70.17 & 7.02 & 22.81 & 1.20 & 0.24 \\
\hline 466 & 9 & $21-9,126 \mathrm{~cm}+29-2,46 \mathrm{~cm}$ & 4.02 & 1.35 & 63.46 & 6.59 & 29.95 & 1.25 & 0.35 \\
\hline
\end{tabular}




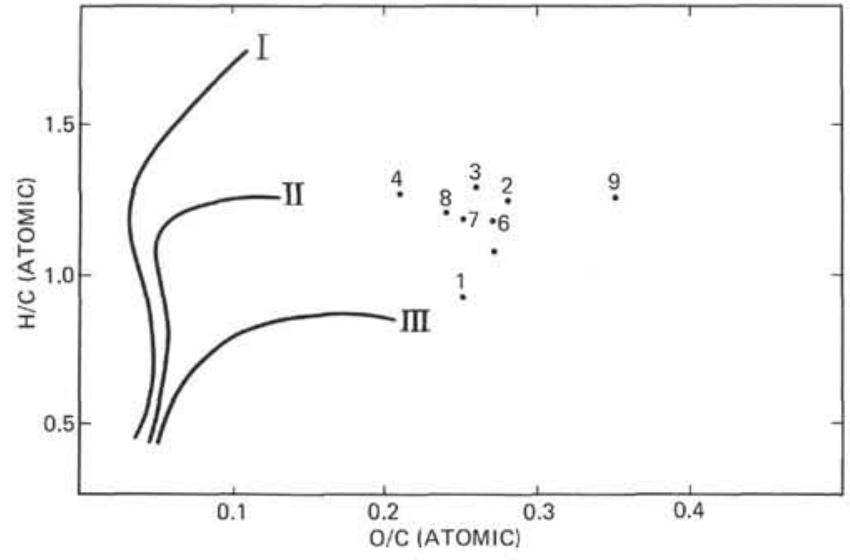

Figure 3. Diagram for determination of kerogen type (after Van Krevelen, 1951/1952). I: sapropelic organic matter; II: mixed (sapropelic-humic, humic-sapropelic); III: humic. Numbers correspond to samples in Table 2.

dant semi-dissolved coccoliths, numerous radiolarians, fragments of volcanic glass, siliceous sponge spicules, single fish bones, and lenses of montmorillonite-illite clay. The sediments are characterized by a larger or smaller admixture of authochthonous sapropelic substance, which is localized in veins, mottles, and lenticular areas of brown tints. This uneven distribution of organic matter is responsible for distinct horizontal, horizontally wave-like, and frequently interrupted microlamination of sediments.

Sapropelic matter is represented by sapro-collinite with evenly distributed inclusions of alginite-thallomite. Allochthonous and autochthonous humic materials are nearly absent. This testifies to the remoteness of the sedimentation zone from land. As a result, terrigenous material in sediments is represented by quartz and feldspar grains in small amounts. Faunal remains are represented by sporadic inclusions of fish bones and planktonic organisms. Authigenic minerals are represented by globular opal, clinoptilolite, calcite, and a small admixture of pyrite. Pyrite is dispersed in sapro-collinite, sometimes replaces alginite-thallomite, and is associated with radiolarians. Some intervals of the section (Core $70-5,99-100 \mathrm{~cm}$; Core 70-6, 42-43 cm) are enriched in pyrite.

The carbonate content of sediments of this genetic type depends mostly on abundance of coccoliths and the presence of authigenic calcite, varying from 25 to $35 \%$. Its increase or decrease in some layers of the section is related mostly to variations of organic matter and biogenic-silica contents in sediments.

The absence of humic material in the sediment, the slight admixture of terrigenous mineral components, the abundant radiolarians, and the enrichment in autochthonous sapropelic substance enable us to assume that sediments of this type were found in the zone of relatively deep-sea sedimentation.

During the accumulation of lower Aptian sapropelic sediments, in the vicinity of Sites 463 and $465 \mathrm{~A}$, no redeposition of sediments enriched with organic matter appears to have taken place. Their formation began in the late Albian with sapropelic and humic-sapropelic foraminifer-nannofossil limestones overlying trachytes.

While analyzing these deposits, it became evident that they are composed of five genetic types of sediments that correspond to two facies and are attributed to one macrofacies of sapropelic and humic-sapropelic carbonate deposits of the near-shore sedimentation zone (Table 1). The boundaries of genetic types and facies in a series of sediments of this macrofacies were drawn arbitrarily, because of low core recovery. The base of the foraminifer-nannofossil limestones containing organic matter (Cores 37-40) belongs to the facies of carbonate sediments with autochthonous sapropelic and allochthonous humic microcomponents of the shallowwater, near-shore sedimentation zone. The zone is represented by two genetic types of sediments Core 40; Section 39-1, 113-114 cm; and Section 39-1, 112-113 $\mathrm{cm}$; Core 37) that differ in structural features, content and size of inclusions of humic material, amount of terrigenous mineral substance, and composition of carbonates. The sediments of both genetic types belong to sapropelic and humic-sapropelic foraminifer-nannofossil limestones, the color of which in a sample varies from gray to dark-gray, sometimes black with an olive tint. The change of color of sediments is due to differences in amount of organic matter, varying from 0.2 to $3.5 \%$ (one type) and 0.1 to $7.5 \%$ (second type). The organic matter of both genetic types, along with sapropelic material composed of sapro-collinite and alginitethallomite, contains an admixture of humic material in the form of small and large (up to $2.5 \mathrm{~cm}$ ) fragments of allochthonous structureless gelinite-telinite "A" (vitrinite) of red-brown color, and sporadic fragments of tissues represented by gelinite-telinite " $C$ "' and, perhaps, gelinite-collinite. The genetic type of sediments occurring at the base of the interval proved richer in humic material, as compared to its content in sediments of the overlying type. The inclusions of the latter are characterized by a larger size.

The types are characterized by distinct localization of the organic matter. As a result, in microstructure of sediments of both types there are well-outlined bands, veins, strands, and lenticular to band-like areas enriched with organic matter. This proves responsible for horizontally wave-like (Plate 1, Fig. 3), in places unidirectional, flat cross-lamination, sometimes with signs of scour (Plate 1, Fig. 4; Plate 2, Fig. 1) prevailing in sediments of the base of the interval. Higher in the section, the lamination becomes horizontal, in places with small gentle, oblique laminations. Macroscopically, this results in alternation of beds of various thickness and extent, differing in intensity of colors and sometimes grain size of the material.

Both genetic types abound in carbonate material-from 55.0 to $90.8 \%$. These variations are largely related to the content of organic matter. Under a microscope, it consists mostly of fine calcite aggregates that are products of recrystallization of carbonate microorganisms, and, mainly, coccoliths. Relics of the latter are frequently visible in sediments. Authigenic dolomite 
is also observed in the carbonate material. It occurs as single rhombs dispersed in the sediment, and forms interbeds rich in this material (Section 40-1, 120-121 cm; Section 40-2, 20-23 cm).

Terrigenous material in sediments of both types is composed mostly of gravel- and sand-sized grains of quartz and feldspar, and sometimes of biotite flakes. Terrigenous material in sediments at the base of the interval is more coarse-grained. Sediments of this type contain fragments of strongly weathered basalts and interbeds of montmorillonitic clay with an admixture of illite (Section 40-2, 7-8 cm). The montmorillonite clay is a product of alteration of volcanic ash.

Sediments of this interval contain foraminifer tests with chambers filled with recrystallized calcite, large and small fragments of mollusk tests, skeletons of various organisms, and inclusions of fish bones of various sizes. Appreciable amounts of pyrite are recognized throughout the interval in tests of foraminifers, in alginite-thallomite, or dispersed in the sapropelic substance of the sediment.

Noteworthy are allochthonous and autochthonous humic microcomponents testifying to the erosion of material from land, and likely from underwater rises. These source areas were near the sedimentation basin (shallow near-shore zone). This is confirmed by appreciable amounts of quartz and feldspar grains, as well as by textural peculiarities of the sediments: distinct, horizontally wave-like, cross, horizontal, and small, gentle cross-lamination. Rather large fragments of mollusk tests belonging to benthic, shallow-water bivalves, ostracodes, and other organisms found in these sediments, bespeak near-shore, shallow-water accumulation of sediments.

A decrease in number and size of inclusions of allochthonous and humic and terrigenous material upward in the section shows that at the very beginning of formation of sediments enriched with organic matter the sedimentation basin was nearer the source area than later. The considerable amount of crystals and interbeds of dolomite at the base of the interval appears to testify to the existence of saline lagoons in the near-shore zone of the sea. The change from horizontally wave-like lamination and cross-lamination to horizontal and small, gentle cross-lamination bespeaks a gradual increase in distance between the sedimentation basin and the coast, i.e., to progressive transgression.

Higher in the section, the sapropelic deposits of Cores 32 to 36 belong to the facies of carbonate sediments with prevailing autochthonous sapropelic microcomponents of organic matter of a relatively deepsea, near-shore sedimentation zone, and can be attributed to the same macrofacies as the underlying interval of the section. This facies is composed of three genetic types represented respectively by the intervals from Cores 36 to $32-1,94-95 \mathrm{~cm}$; from $32-1,58-59 \mathrm{~cm}$ to Core 28 ; and from Core 27 to Core 26 ), successively replacing each other upward in the section, from the upper Albian to the lower Cenomanian inclusive (Table 1; Fig. 2). They differ in textural peculiarities and organicmatter content.
Sediments of all three genetic types are represented by gray, dark-gray, and black with an olive tint foraminifer-nannofossil limestones, sometimes marls.

The organic matter in these types varies from 0.1 to $8.6 \%$ and consists mostly of sapro-collinite and alginite-thallomite. It is characterized by an insignificant admixture of humic material in the form of fragments of gelinite-telinite " A" (vitrinite) that is more common in the underlying interval. Veins of gelinite-telnite " $C$ " are sometimes observed as well.

Distribution of organic matter in sediments of these genetic types is not even. As a result, each of them has its peculiar textural features. The localization of organic matter in lenses, bands, and veins with different distinctness of boundaries, is responsible for horizontal lamination, and in places small, gentle cross-lamination of sediments at the base of the interval (upper Albian, Plate 2, Figs. 2, 3). Higher in the section, the sediments (upper Albian) are characterized by more or less distinct horizontal lamination (Plate 3, Figs. 1, 2). Sediments of the lower Cenomanian show homogeneous or slightly horizontally laminated texture (Plate 3, Fig. 3). This is due to a more or less even distribution of organic matter in the sediment. In some places, it is localized in separate mottles with obscure outlines.

The material composition of sediments of all three genetic types abounds in fine calcite aggregates, locally with interbeds consisting of coarsely crystalline calcite (31-1, 28-29 cm, and elsewhere).

As in sediments of the lower interval of the described strata, the carbonate material is a product of recrystallization of coccoliths and other carbonate organisms.

Terrigenous minerals are nearly absent, or found as single quartz and feldspar grains.

Authigenic minerals are represented by negligible amounts of pyrite and barite associated with foraminifer tests or filling cavities.

Faunal remains are represented by numerous foraminiferal tests, small amounts of fish bones, and rare fragments of mollusk shells, rather large in places and visible even in hand sample (Plate 3, Fig. 4). Burrows are observed too. Radiolarians are as a rule replaced by calcite.

A slight admixture of humic material in the composition of organic matter and terrigenous minerals in sediments of the above-mentioned genetic types of the interval shows that their formation proceeded in a relatively off-shore sedimentation basin that was in a relatively deep-sea, near-shore zone. This facies environment can also be evidenced by enrichment of genetic types of sediments with sapropelic material, the greater part of which is of algal origin. The replacement of sediments with horizontal and small, gentle cross-lamination upward in the section by sediments with predominant horizontal lamination, and further by almost homogeneous or slightly horizontally laminated sediments, characterizes the process of deepening the sedimentation zone and moving it offshore, as sediment accumulation peculiar to the given interval developed.

So, if the accumulation of sapropelic deposits at Site 465 began under shallow-water conditions of the near- 
shore sedimentation zone (sometimes with saline lagoons, perhaps), it ended under conditions of relatively deep-water, remote from the shore, and evidently in the same near-shore sedimentation zone. This deepening of the basin throughout the Late Cretaceous and early Cenomanian corresponded to a successive change of genetic types of sediments and their facies in a section of sapropelic deposits from the basement up through the section.

The formation of sapropelic deposits at Site 466 in the late Albian began with the facies of carbonate sediments with autochthonous sapropelic microcomponents of organic matter of the relatively deep-water, nearshore sedimentation zone. There are no shallow-water sediments at the base of sapropelic deposits at Site 465 . The sediments of the given facies at Site 466 , contrary to those at the other sites, are not consolidated.

In the specific features of the material composition and facies, the strata of sapropelic deposits at Site 466 correspond to an interval at Site 465 and belong to the same macrofacies.

Cretaceous deposits at Site $\mathbf{4 6 6}$ are composed of one genetic type of sediments (Table 1). These are sapropelic calcareous foraminifer-nannofossil oozes, gray to dark gray, and black with an olive tint, with distinct roiling structures (Plate 3, Fig. 4), non-laminated or with obscure horizontal lamination. The sediments are enriched in chert and contain small, lenticular inclusions of darkgray clay.

Microscopic study allowed us to see an abundance of heavily dissolved coccoliths and numerous foraminifer tests, the chambers of which are filled with recrystallized calcite or cristobalite. Radiolarians, fish bones, and rare fragments of mollusk shells can be observed too.

The organic matter is represented by sapro-collinite and alginite-thallomite, rare fragments of gelinitetelinite " $A$ " (vitrinite), inclusions of gelinite-telinite " $C$," and fusinite. The latter is characterized by tissue remains of cellular structure. The organic matter content in sediments of this type varies within broad limits-from 0.1 to $7.5 \%$. The type is characterized by even distribution of organic matter, occasioning the homogeneous texture of its sediments.

Terrigenous material is nearly absent. There are fragments of volcanic glass. The clay matter consists of $\mathrm{Fe}-$ montmorillonite and illite-montmorillonite. Authigenic minerals are mainly pyrite, the crystals of which are frequently developed in radiolarians, in foraminifers, in alginite-thallomite, or dispersed in the sapropelic substance of the sediment. Single grains of glauconite and inclusions of coarsely crystalline calcite are observed here. The carbonate content varies from 20 to $95 \%$.

No regular change of material composition of sediments in the section of foraminifer-nannofossil oozes has been recorded.

Enrichment of sediments of the given genetic type with autochthonous sapropelic material, mostly of plant origin, speaks in favor of their origin under conditions of a near-shore sedimentation zone.

An insignificant admixture of allochthonous and autochthonous humic material in the organic matter of the sediments, and the almost complete absence of terrigenous minerals in them, shows that the source of material supply from land at the time of formation of the strata was not near. So, the sedimentation basin in the near-shore zone was relatively remote from the shore. The facies environment, as shown above, was peculiar to the time of formation of the upper interval of sapropelic deposits at Site 465 .

\section{REFERENCES}

Bogolyubova, L. 1., and Timofeev, P. P., 1978. Composition of the "black shales" organic matter of the Cape Verde Basin (East Atlantic) and their oil-generating potential. Litologiya Poleznye Iskopaemye, No. 5. [in Russian]

Timofeev, P. P., and Bogolyubova, L. I., 1979. Black shales of the Bay of Biscay and conditions of their formation: Deep Sea Drilling Project Leg 48, Holes 400, 402A. In Montadert, L., Roberts, D. G., et al., Init. Repts. DSDP, 48: Washington (U.S. Govt. Printing Office), 831-854.

Van Krevelen, W., 1951/1952. De Chemie van de Steenkoholen en het in kollingsporoces. Natuurkundige Voordrachten, wiemws keeks, 15 abb., No. $30,71-88$.

Vassoevich, N. B., 1975. Origin of oil. Vestnik MGU, No. 5. [in Russian] 


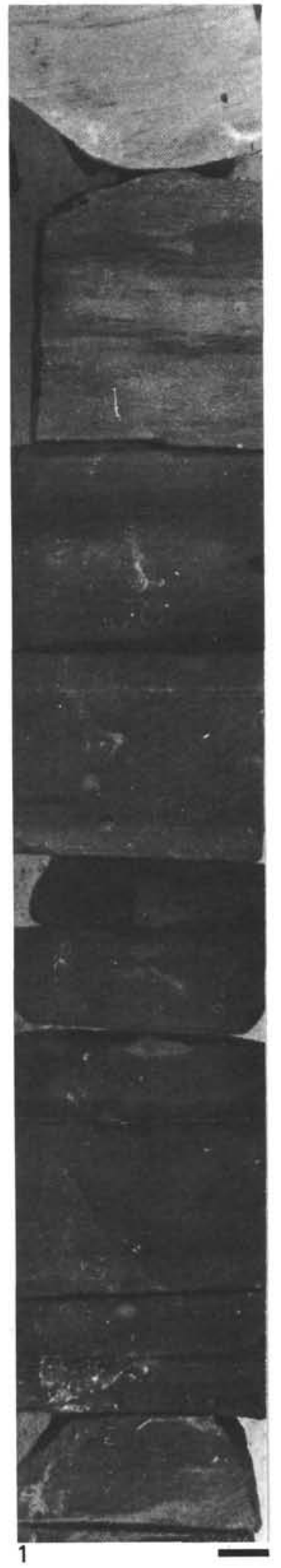

Plate 1. Sediments.

Figure 1. Siliceous limestone, gray to dark-gray, sometimes black with an olive tint, with more or less distinct lamination, organic matter $(0.1-5.5 \%)$ of sapro-collinite and alginite-thallomite composition. $463-70-5,80-110 \mathrm{~cm}$.

Figure 2. The same type, but with chaotic bedding. 463-70-1, 115-137 $\mathrm{cm}$.
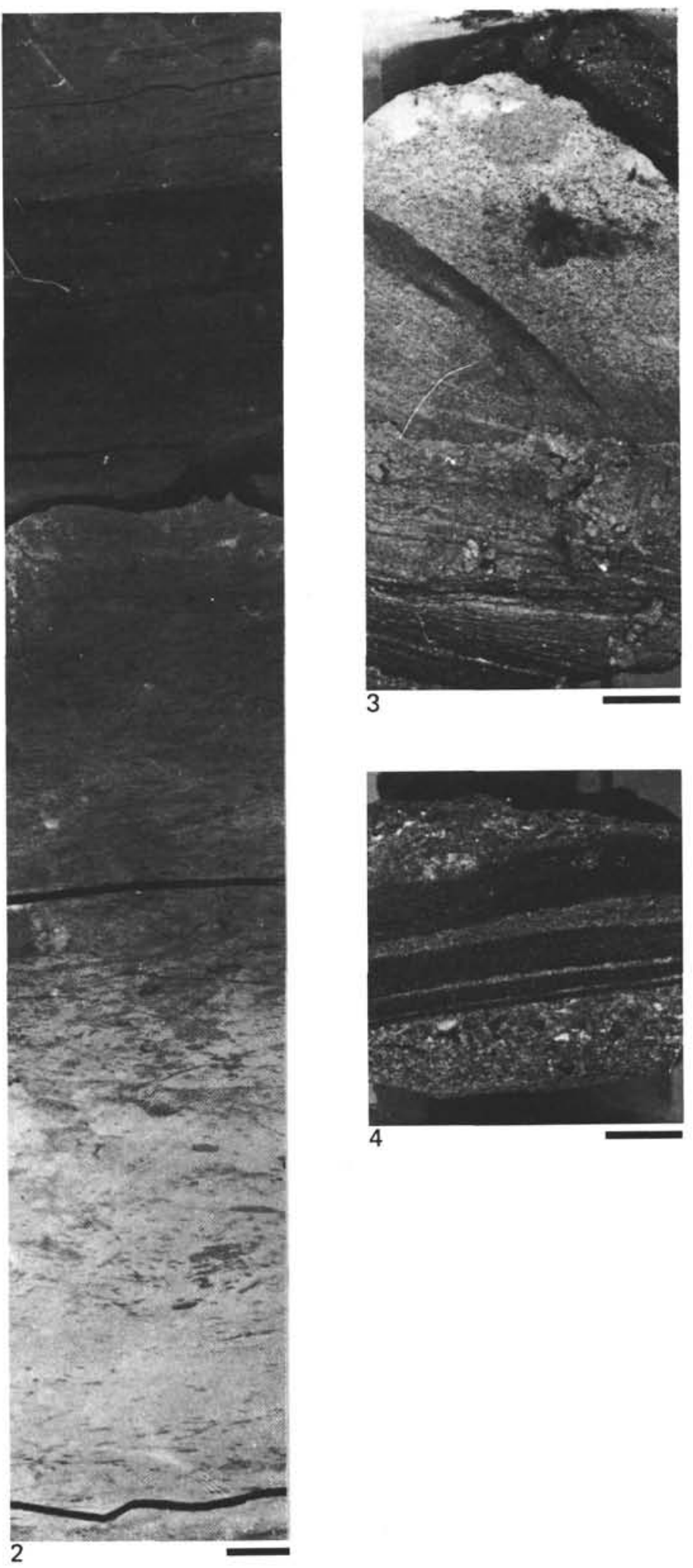

Figure 3. Foraminifer-nannofossil limestone, gray to dark-gray with an olive tint, with horizontally wave-like or partly horizontal bedding, a higher content of terrigenous material, crystals and interbeds of dolomite, organic matter $(0.2-3.5 \%)$ of sapro-collinite and alginite-thallomitic composition, abundance of vitrinite. $465 \mathrm{~A}-40-1,125-140 \mathrm{~cm}$.

Figure 4. The same type. $465 \mathrm{~A}-40-1,120-123 \mathrm{~cm}$. 

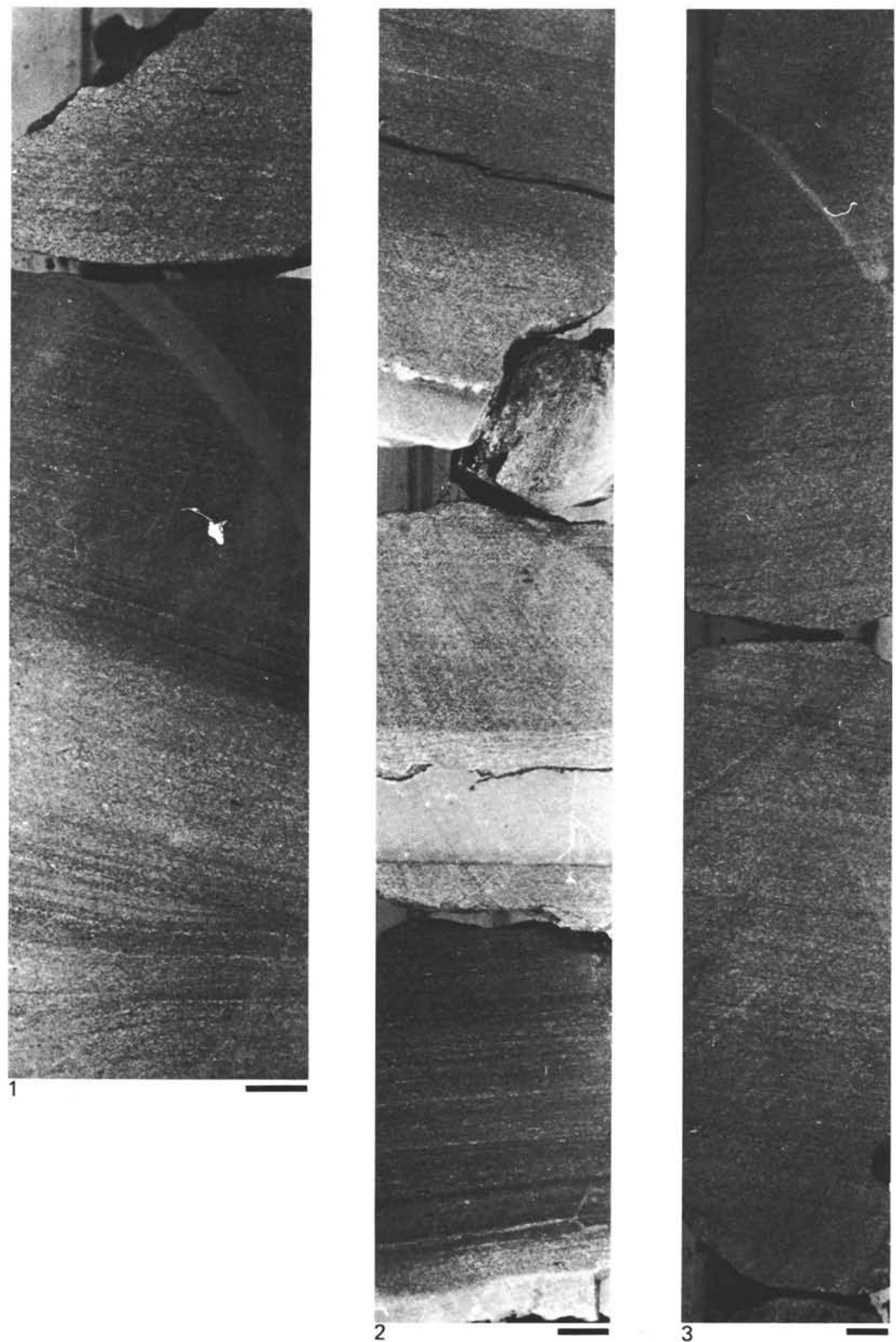

Plate 2. Sediments.

Figure 1. Foraminifer-nannofossil limestone, gray to dark-gray with an olive tint, unidirectional flat cross-lamination, admixture of terrigenous material, organic matter $(0.2-3.5 \%)$ of sapro-collinite and alginite-thallomite composition, abundance of vitrinite. $465 \mathrm{~A}-40-1,90-110 \mathrm{~cm}$.
Figure 2. Foraminifer-nannofossil limestone, gray to dark-gray and black with an olive tint, horizontal lamination, in places small, gentle, cross-lamination, organic matter $(0.1-8.6 \%)$ of saprocollinite and alginite-thallomite composition. 465A-36-2, 50-75 $\mathrm{cm}$.

Figure 3. The same type. 465A-33-2, 35-65 cm. 

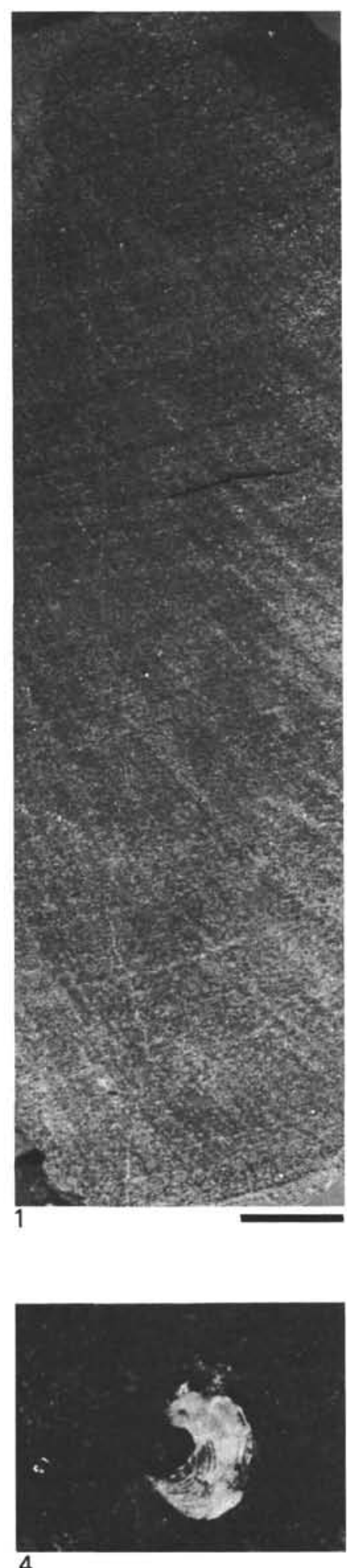

4

Plate 3. Sediments.

Figure 1. Foraminifer-nannofossil limestone, gray sometimes darkgray and black with an olive tint, predominantly more or less distinct horizontal lamination, organic matter (0.1-1.9\%, sometimes $6.1 \%$ ) of sapro-collinitic and alginite-thallomite composition, $465 \mathrm{~A}-30-1,60-70 \mathrm{~cm}$.

Figure 2. The same type. $465 \mathrm{~A}-29-1,100-120 \mathrm{~cm}$.
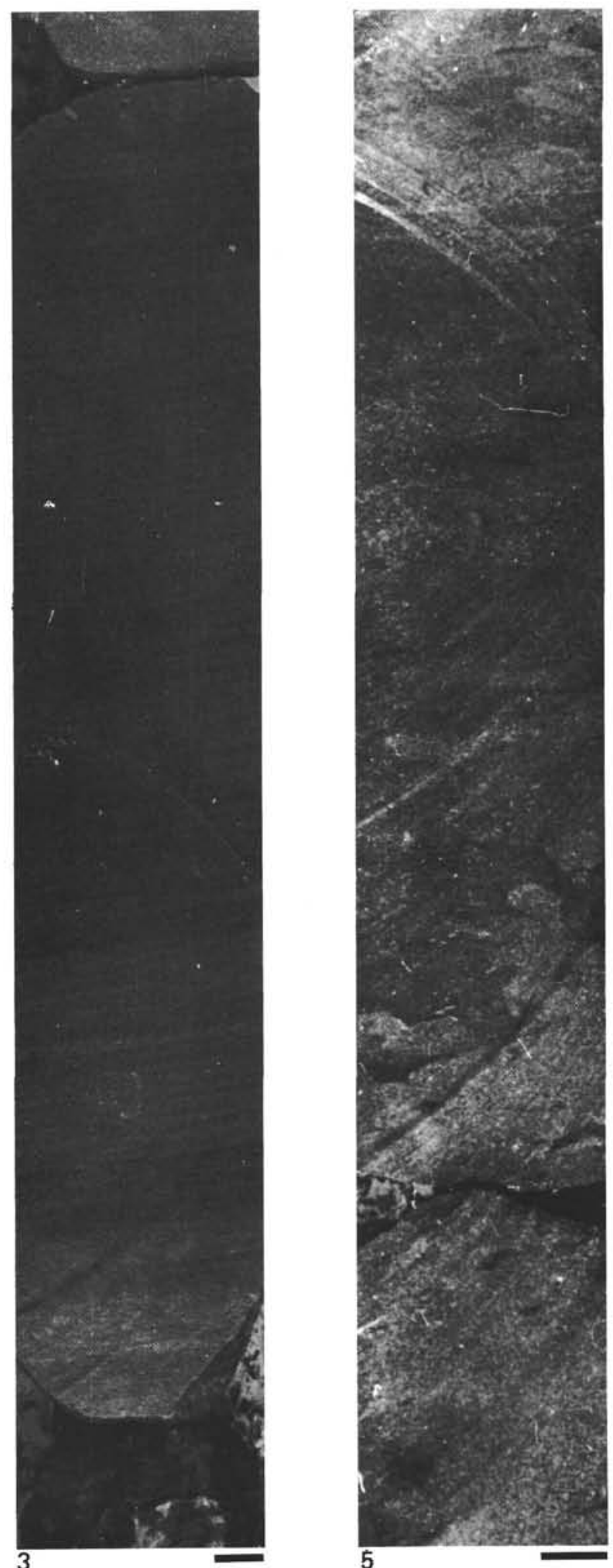

Figure 3. Foraminifer-nannofossil limestone, gray to dark-gray with an olive tint, homogeneous, in places slightly horizontally laminated, with organic matter $(0.1-2.5 \%)$ of sapro-collinite and alginite-thallomite composition. $465 \mathrm{~A}-27-2,80-110 \mathrm{~cm}$.

Figure 4. A fragment of a mollusk test in foraminifer-nannofossil. $465 \mathrm{~A}-28-2,35 \mathrm{~cm}$.

Figure 5. Foraminifer-nannofossil ooze (chalk), gray to dark-gray and black with an olive tint, homogeneous, with distinct rolling structures, organic matter $(0.1-7.5 \%)$ of sapro-collinite and alginite-thallomite composition. $466-34-2,20-40 \mathrm{~cm}$. 